\title{
温浴施設での薪ボイラー導入における運用実態 一木質バイオマスの小規模熱利用が地域に与える影響とは一
}

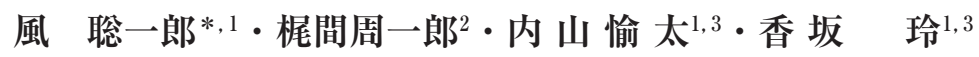

\begin{abstract}
近年，山間地などを中心に全国で温浴施設等への薪ボイラーの導入事例が見受けられるようになった。薪は製造が簡単であ るというメリットがある一方で然料投入を人力に頼るため, 一定規模以上での利用は不向きであるとされ， $100 \mathrm{~kW}$ 以上の規模 での事例研究は限定的である。本研究では二つの $100 \mathrm{~kW}$ 以上の薪ボイラー導入事例を対象に調查を行った。結果, (1) 灯油ボ イラー使用時と比較し燃料コストが削減されており，木質エネルギーへの代替率も $70 \%$ を超え，（2）予測通り人力での薪の投 入は薪ボイラー使用者への負担となっている。一方で,（3）薪投入によって追加的な人件費が発生するといった経営面への影 響は見受けられず，(4) 熱提供の形態によっては利用者側の負荷を軽隇できる可能性があることが明らかとなった。 キーワード：再生可能エネルギー，木質バイオマス，小規模熱利用，薪，自治体
\end{abstract}

\begin{abstract}
Soichiro Kaze, ${ }^{*, 1}$ Shuichiro Kajima, ${ }^{2}$ Yuta Uchiyama, ${ }^{1,3}$ Ryo Kohsaka ${ }^{1,3}$ (2017) Introducing Wood Log Boilers in Spa Facilities: Impacts of Small Scale Heat Utilizations of Woody Biomass on Regions of Japan. J Jpn For Soc 99: 18-23 In recent years, wood $\log$ boilers have been introduced to hot water bathing facilities or spas in Japan, particularly in mountainous areas. Producing wood logs is relatively easy, on the other hand, input of wood logs into the boilers has to be done manually, and it is pointed out that wood log boilers are not efficient if they are used as facilities generating over $100 \mathrm{~kW}$. In this context, the cases discussed in academic papers are limited to small scale ones. In this paper, the analysis of two cases of boilers generating over $100 \mathrm{~kW}$ are examined to verify potentials of the large scale facilities with wood logs. It reveals that (1) operating costs are reduced compared with the system using kerosene, and substitution rates are over 70\% (2) manual input of wood logs was a certain load on the boiler users; (3) impacts on the managements, such as rise of labor costs caused by the manual input of wood log, were not seen and (4) wood log systems can potentially reduce the loads on the facilities depending on heat supply systems.

Key words: renewable energy, woody biomass, small scale heat utilization, wood log, municipality
\end{abstract}

\section{I. 日本における木質バイオマス発電の概況と課題}

近年，公共施設や一般家庭に执いて，木質バイオマスを 燃料とするボイラーやストーブの導入が進んでいる。林野 庁（2016）によると，我が国に打ける木質資源利用ボイ ラーの導入数は 1999 年で 174 基だったものが 2014 年で 2,023 基となっている。

特に 2012 年の固定価格買取制度（FIT）導入以降は木質 バイオマス発電所の建設が全国的に行われている。FIT の 認定を受けた発電設備の稼働もしくは計画は 2015 年 10 月 末現在で全国 56 力所が認定されている。うち $2,000 \mathrm{~kW}$ 以上の発電所が 46 力所で, その大部分が $5,000 \mathrm{~kW}$ 級の 木質バイオマス発電所となっている（林野庁 2016）。

全国各地で整備事業が行われている FIT を利用した発電 設備に関して, $5,000 \mathrm{~kW}$ 級の発電所 1 力所につき年間で 10 万 $\mathrm{m}^{3}$ 近くの木質燃料を使用するため, 膨大な量を要す る。そのため燃料となる未利用材の供給量が不足する可能 性が指摘されている。この要因として外部資本による開発 によって大規模発電に特化した計画が多いことが挙げられ る。また運用, 制度設計, エネルギー効率に課題があると の指摘もなされている。特にエネルギー効率においては発 電専用では $20 \%$ 程度にしかならないため燃焼時に発生す
る熱も同時に利用する熱電併給の促進が主張されている (安藤 2014 ; 金澤 2014 ; 近藤 2015)。

木質バイオマスのエネルギー利用は FIT 認定の発電所建 設の増加により，一般的にはバイオマス =発電というよう に認知されがちである。一方で熱利用を行っている事例も 国内に存在する。

山下・藤井（2015）が実施した全国 1,741 の基礎自治体 全てを対象とした「全国市区町村再生可能エネルギー実態 調查」では, バイオマスの熱利用を行っている自治体は 118 と相対的に少なくなっている。要因として原料調達や 熱需要の確保が課題となり, 既に利用されてきた資源を新 たな用途に使用するため, 既存の権利主体との利害調整が 求められるためと述べている。一方で前述の山下・藤井 (2015) が実施したアンケート調查の結果では, 資源活用, 経験蓄積, 雇用など再生可能エネルギーの地域活性化への 期待の高さが確認されており, またエネルギーの専門部署 を設け積極的に再生可能エネルギーに取り組んでいる自治 体にはバイオマス熱利用施設が設置されているという傾向 があるとしている。

このようなバイオマスのエネルギー利用による地域活性 化への期待の背景として, 伊藤 (2012) は, 東日本大震災 を境に自然エネルギーは単なる代替エネルギーにとどまら

*連絡先筆者（Corresponding author）E-mail: kaze.soichiro@gmail.com

1 金沢大学大学院人間社会環境研究科地域創造学専攻 テ920-1192 石川県金沢市角間町 (Division of Regional Development Studies, Graduate School of Human and Socio-Environmental Studies, Kanazawa University, Kakuma, Kanazawa, Ishikawa 920-1192, Japan)

2 金沢大学人間社会学域地域創造学類 $\bar{T} 920-1192$ 石川県金沢市角間町 (School of Regional Development Studies, College of Human and Social Sciences, Kanazawa University, Kakuma, Kanazawa, Ishikawa 920-1192, Japan)

3 東北大学大学院環境科学研究科先進社会環境学専攻 邓980-0845 宮城県仙台市青葉区荒巻字青葉 468-1 (Department of Environmental Studies for Advanced Society, Graduate School of Environmental Studies, Tohoku University, Aoba 468-1, Aramaki, Aoba-ku, Sendai, Miyagi 980-0845, Japan)

(2016 年 6 月 27 日受付, 2016 年 11 月 9 日受理) 
ず, 地域の自立やエネルギー自治の確立の手法になり得 る, あるいは経済・産業構造のグリーン化という新たな地 域発展戦略の中核に位置付く存在であるといった議論が少 なくとも研究者レベルでは行われていると述べている。

FIT 認定設備の多くを占める $5,000 \mathrm{~kW}$ 級の木質バイオ マス発電所では, 地域内での燃料の調達が難しいという問 題がある。また発電専用ではエネルギー効率が悪く, 熱電 併給の促進が課題となっている。木質バイオマスのエネル ギー利用は，外部資本の開発による大規模利用ではなく地 域の様々なステークホルダーが協同し，地域の自立やエネ ルギー自治の手法として地域の実情に合わせた利用が望ま しいといえる。

\section{II. 木質バイオマスエネルギーの熱利用に関する議論}

本章では，木質バイオマスエネルギーの熱利用に関する 先行研究を整理する。

木質バイオマスのエネルギー利用の技術において, 熊崎 （2011）は木質バイオマスによる熱電併給技術について, これまで開発もしくは提案されているものの中で成熟段階 にあるのは直接燃焼方式の蒸気エンジン/タービンのみで あるとしている。またバイオマスから効率よく電気をとる ということは難しく，熱の生産をメインにして無理のない 範囲で電気をとることが本筋のように思われると述べてい る。

熱利用を前提とした木質バイオマスの利用において，相 川（2014）は事業のプランニングにおいてバイオマスボイ ラーは化石然料ボイラーと比較しかなり高額であるが，燃 料費においては化石然料よりバイオマスの方が安く設定で きる点を指摘している。一方でバイオマスボイラーの償却 期間が 15 年と長期の償却を考えなければならない点を指 摘している。発電事業でFITによる 20 年間という長期の 買い取りが保証されている場合と比較し，熱利用の場合は 同様の保証がなくリスクが高いため金融機関から融資を受 けるのはハードルの高い状況にあるとしている。したがっ て，補助金を使って公共施設への導入にとどまるのは当然 であり，民間に広がることは難しいと述べている。

海外での木質バイオマスエネルギーの利用形態につい て，三浦（2013）は再生可能エネルギーの導入が進んでい るスウェーデンおよびオーストリアの状況を取り上げてい る。両国ではエネルギー源を木質バイオマスとする地域熱 供給が普及しており, 熱供給会社が燃料の手配と投入, 設 備の保守を担当し, 熱を提供し使用料を徵収している。こ の方式は電気や水を利用するのと同じ形で利用できるた め, 木質バイオマス利用における究極の形であると論じて いる（注 1)。ノルウェーにおける木質バイオマス利用に ついて分析している Trømborg ら（2008）では, 熱電併給 を行う有用性を指摘している。今後のノルウェーにおける バイオマス利用は化石燃料などの他の燃料に対しても競争 的であり，特に薪ストーブの利用や石油ボイラーから薪ボ イラーへの転換は現状進んでいるとしている。一方で木質 バイオマスによる熱利用システムは依然としてエネルギー 価格が高くなってしまう課題があるとしている。
木質バイオマスのエネルギー利用の際の燃料形態につい ては, 前述の相川（2014）と熊崎（2013）で触れられてい る。両者の内容を整理すると, 製造は容易であるが, 運用 において人力によるところの大きい薪は $100 \mathrm{~kW}$ 未満の小 規模利用が適正であり, チップは安価で燃焼機器の規模に 対する汎用性が高い一方で, 形状や含水率等の品質面おい て留意する必要があるとしている。またペレットは単位エ ネルギーが高い上に品質が安定しており, 燃焼機器の規模 も $20 \mathrm{~kW}$ から $1 \mathrm{MW}$ のものまで広く使用できるというメ リットがあると評価している。Pa ら（2013）は, カナダ のブリティッシュコロンビア州において家庭用の暖房とし て利用されている薪を全てペレットに置き換えた場合に環 境に与える影響の数值化および環境污染によって発生する 外部コスト, 燃料コストがどのように変化するかをシミュ レーションしており，環境に与える影響および外部コス ト, 燃料コストの削減は可能であるとの結果を示してい る。しかしながら日本におけるエネルギー価格を比較した 上で, ペレットの材料となる製材の生産構造が欧州と国内 では異なるため, 経済性を持ったペレットを選択肢に入れ ることができる地域は限られると指摘がなされている（相 川 2014)。

海外, 特に木質バイオマス利用の先進国であるオースト リアの木質バイオマス燃料の需要をみてみると, 薪の需要 が一番多く, 次いでチップ・バーク, 熱電併給用チップ, ペレットとなっている。そのうち薪は薪ボイラーでの需要 である。なおオーストリアでの薪ボイラーの用途はほぼす べてが個人宅用での家庭規模程度での熱源となっている (注 2)。

以上より，木質バイオマスの利用においては，直接燃焼 方式での熱利用をメインに考える必要がある。その然料に は薪, チップ, ペレットがあるが, それぞれに長短があ り, 燃焼機器の規模による燃料の選択は, チップ, ペレッ 卜は広範に使用できるのに対し，薪は $100 \mathrm{~kW}$ 未満の使用 が適切であるという点が整理された。また海外の先進国で あるスウェーデンやオーストリアでは熱供給会社による地 域熱供給が普及しており，インフラとして整備されている 一方で，オーストリアでは薪ボイラーが一般家庭用の熱源 として普及しており, 後述の温浴施設へ薪ボイラーを導入 するという日本の事例は特徴的であるといえる。

\section{III. 先行研究での課題}

先行研究において薪は $100 \mathrm{~kW}$ 未満の規模での利用が好 ましいとされている中で, 最近では $100 \mathrm{~kW}$ 以上の熱需要 を要する温浴施設等に対して, 熱源として薪ボイラーの導 入を行う事例が国内ででてきている。今回の調査対象とし た A 村, B 市以外にも, 例えば季刊地域編集部 (2013) では福島県鮫川村の温浴施設に $75 \mathrm{~kW}$ の薪ボイラー 4 台 が導入されていると紹介されており，また相川ら（2016） では, 長野県根羽村 $(170 \mathrm{~kW}$ の薪ボイラー 1 台を導入) や徳島県三好市 (5 力所の温浴施設に $75 \mathrm{~kW}$ の薪ボイラー 計 15 台を導入）の事例が記載されている。富山県南砺市 は, 同市の掲げる「エコビレッジ構想」において今後, 市 
内の温浴施設 4 力所に薪ボイラーを整備する計画である (注 3$)$ 。このことから薪ボイラーの導入が国内で注目され てきており, 今後も導入数が増加するのではないかと考え られる。

薪ボイラー導入のメリットとして, 森（2016）は未利用 の $\mathrm{C}$ 材を使ったボイラー用薪の原木は製紙用チップの原 木よりも高く買い取られるメリットがあると指摘してい る。薪の製造に大きな機械が不要で，薪ボイラー導入施設 という薪の販売先も確保できるため, 低投資, 低リスクで あるとしている。また薪ボイラーへの薪の自動投入装置が ない分設備費が安価になるため，その分雇用として地域に 投資できるメリットがあると述べている。

このように運用面以外に地域に対するメリットも指摘さ れている薪ボイラーであるが，その導入事例を対象とした 研究はほとんど行われておらず，その運用実態は明らかに されていない。また導入後の地域に対する効果の検証も限 定的である。薪ボイラーの導入をはじめとする木質バイオ マスの小規模熱利用は，地域の多様なステークホルダーが 協働し，その地域の資源を利用しエネルギー自治や自立， ひいては地域振興の手法として着目されている中で，実際 の導入事例の検証が限定的であることは，大きな課題であ ると考える。そこで本研究では小規模熱利用の方法の一つ である薪ボイラーの導入事例を調査し，導入後の運用実態 および地域に対する効果（燃料使用量，燃料コス卜，木質 エネルギーへの代替率，雇用の有無）を明らかとすること を目的とした。調査対象となる事例については，ボイラー 起因による運用負荷のバイアスを避けるため同一メーカー のものを導入している事例を調査対象とした。これらの条 件に該当する事例として，中国地方の $\mathrm{A}$ 村および中部地 方の B 市を調査対象とした。

\section{IV. 調査対象と方法}

調査対象の $\mathrm{A}$ 村は中国地方の山村で，人口約 1,500 人 （2015年 1 月 31 日現在）で，林野率は $95 \%$, 人工林率 85\%の地域である。B市は中部地方の山間地に位置し, 人口約 44,000 人 $(2010$ 年 10 月 1 日現在)で，林野率 $90 \%$, 人工林率 $56 \%$ の地域である（表-1）。

調査方法・期間について, A 村は 2015 年 10 月 13 日か ら 19 日まで滞在し，熱供給会社 Cでインターンシップを 行いながら同社および $\mathrm{A}$ 村の行政担当者への聞き取りを 行った。また事業内容, 燃料使用量や燃費のデー夕等の資 料の提供を受けた。一方，B市は 2015 年 12 月 29 日に同 市を訪問し，B市担当者，薪供給事業者 $\mathrm{E}$ 代表，温浴施設 $\mathrm{F}$ 支配人より聞き取りを行い，また $\mathrm{A}$ 村同様に資料の提

表-1. A 村および B 市の概況

\begin{tabular}{ccccc}
\hline 対象地 & 人口 & $\begin{array}{c}\text { 面積 } \\
\left(\mathrm{km}^{2}\right)\end{array}$ & $\begin{array}{c}\text { 林野率 } \\
(\%)\end{array}$ & $\begin{array}{c}\text { 人工林率 } \\
(\%)\end{array}$ \\
\hline $\mathrm{A}$ 村 & 1.5 千人 & 57.97 & 95 & 85 \\
$\mathrm{~B}$ 市 & 44 千人 & 1030.79 & 90 & 56 \\
\hline
\end{tabular}

$\mathrm{A}$ 村については $\mathrm{A}$ 村役場提供資料より引用。B 市について人口は B 市 ホームページ記載の人口（最終閲覧日：2016 年 6 月 8 日）を引用。面積, 林野率, 人工林率は「B 市森林整備計画 (2016 年 4 月 1 日樹立) 」より引用。
供を受けた。また両地域とも訪問後に電話等でのフォロー アップを実施し，追って情報や資料の提供を受けている。

\section{V. 調 査 結 果}

本章では $\mathrm{A}$ 村, B 市への調査結果を示す。なお両地域 ともこれまで熱源に灯油ボイラーを使用していた施設に木 質バイオマスボイラーを導入し，それと併用してバック アップおよび熱需要のピーク時対応に灯油ボイラーを使用 している。

\section{1. 薪ボイラー導入の経緯と薪ボイラーの運用実態}

$\mathrm{A}$ 村では村内の村有林を含む民有林の整備事業で発生す る未利用間伐材のエネルギー利用による付加価值化を目的 に， $170 \mathrm{~kW}$ の薪ボイラー 2 台を温浴施設へ導入し 2015 年 2 月から稼働している。この背景には未利用材に付加価值 をつけることで A, B 材を含む搬出木材の売り上げの底上 げを行い，林業振興につなげるという意図がある。薪製造 設備を含めての施設整備費用は約 72 百万円でそのうち約 40 百万円は補助金が充てられている。投資回収は 11 年を 見込んでいる。

燃料に薪を選択した理由は，A 村が想定した集材範囲内 である $\mathrm{A}$ 村および隣接する自治体にチップ工場がなく， またチップ製造設備の導入費用と維持費を勘案した結果, 比較的安価な薪の製造設備の整備と薪製造にかかわる人件 費に投資した方が有効であると判断したためである。原木 は前述の村内で発生する未利用間伐材を森林組合から購入 している。また A 村および隣接する自治体から, 対価の 半分を地域通貨で支払う「木の駅方式」にて住民より集材 している。原木調達の割合は森林組合が 7 割, 木の駅が 3 割（うち約 5 割は村外産）となっている。

聞き取りを基に $\mathrm{A}$ 村の相関を図-1 に示す。

$\mathrm{A}$ 村では薪ボイラー導入時に熱供給会社 $\mathrm{C}$ が導入に関 わるコンサルティングを行い，薪ボイラーを含む関連設備 を温浴施設 D に A 村が設置した。導入後は熱供給会社 C が $\mathrm{A}$ 村より熱供給事業の委託を受け，温浴施設 D に「熱」 を販売している。また熱供給会社 C は燃料となる薪の製 造・投入およびボイラーの保守・管理も担当し必要に応じ て業者の手配を行っている。A 村が採用した地域おこし協 力隊の隊員 1 名を熱供給会社 $\mathrm{C}$ に薪製造・投入の専任社 員として派遣している。なお地域おこし協力隊の隊員にか かる人件費および経費は地域おこし協力隊事業より支出さ

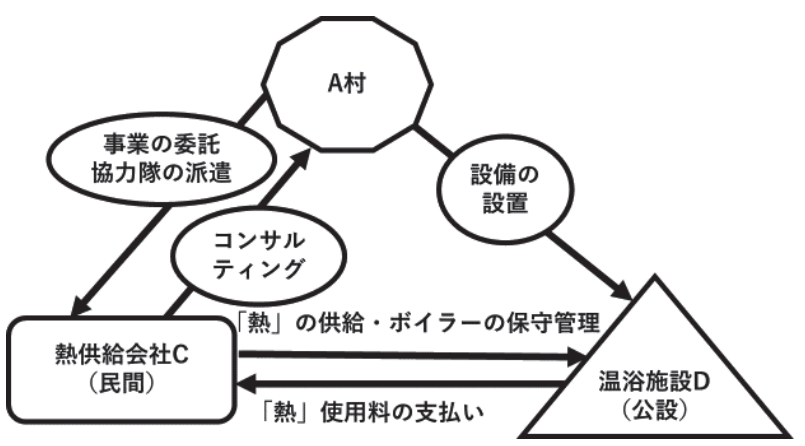

図-1. A 村の関係者の相関

$\mathrm{A}$ 村担当者，熱供給会社 $\mathrm{C}$ への聞き取りを基に筆者作成。 
れていることを付記しておく。

一方， B市では $170 \mathrm{~kW}$ の薪ボイラー 1 台および 400 $\mathrm{kW}$ のチップボイラー 1 台を導入しており, 2014 年 12 月 から稼働している。薪製造設備を含めての整備費用は約 140 百万円であり，そのうち約 70 百万円は補助金が充て られている。投資回収は 15 年を見込んでいる。

導入の背景には地域の森林整備とそこで発生する間伐材 を利用したエネルギー自給のモデルを市内で構築するとい うねらいがある。燃料の選択については, 当初, 市内に燃 料用チップが製造できる業者がおらず，薪であれば薪供給 事業者 $\mathrm{E}$ が対応可能であったため，燃料を全て薪にする 予定であった。しかし検討を重ねる上で温浴施設 F が必 要とする薪を全て供給できるのかという懸念が生じたた め, B 市内で発生する間伐材を約 $50 \mathrm{~km}$ 離れた場所にある 燃料チップが製造可能な業者に運搬しそこで製造したチッ プと，薪供給事業者が製造した薪を，温浴施設 F に供給 する計画に変更した。原木については，薪は市内の林家が 自伐したものや工事支障木を集材しており，すべて B 市 産材を使用している。一方チップはB 市産の間伐材を前 述の業者でチップに加工し供給を受けているのに加え，含 水率が高くチップボイラーが停止するというトラブルが発 生したため, 約 $30 \mathrm{~km}$ 離れた場所にある市外の製材業者 から製材木片を加工した燃料用チップの供給を受けてい る。このトラブルのため, チップボイラーも含めての本稼 働は 2015 年 5 月からとなっている。

聞き取りを基に B 市の相関を図-2に示す。

B 市ではコンサルタント・薪ボイラー事業者 G が木質 バイオマス施設の導入コンサルティングおよび薪ボイラー を販売し， B 市が温浴施設 $\mathrm{F}$ に木質バイオマス施設の整備 を行った。整備後は薪供給事業者 $\mathrm{E} か ゙$ 製造した「薪」を

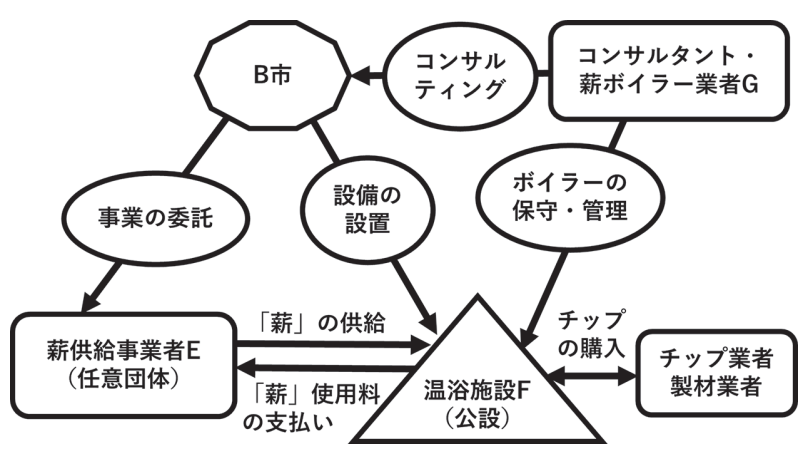

図-2. B 市の関係者の相関

$\mathrm{B}$ 市担当者，薪供給事業者 $\mathrm{E}$ ，温浴施設 $\mathrm{F}$ への聞き取りを基に筆者作成。

表-2. A 村および $\mathrm{B}$ 市の運用形態の差異

\begin{tabular}{lll}
\hline \multicolumn{1}{c}{ 地域 } & \multicolumn{1}{c}{$\mathrm{A}$ 村 } & \multicolumn{1}{c}{$\mathrm{B}$ 市 } \\
\hline 薪の製造 & 熱供給会社 $\mathrm{C}$ が製造 & 薪供給事業者 $\mathrm{E}$ が製造 \\
\hline ボイラーへの薪の投入 & 熱供給会社 $\mathrm{C}$ が投入 & 温浴施設 $\mathrm{F}$ が投入 \\
\hline 温浴施設への提供物 & 熱 & 燃料 \\
\hline ボイラーの管理・保守 & 熱供給会社 C が担当 & 温浴施設 $\mathrm{F}$ が必要に応 \\
& し必要に応じて業者の & じて業者に依頼する \\
& 手配を行う & \\
\hline
\end{tabular}

前述の聞き取り結果を基に筆者作成。
温浴施設 $\mathrm{F}$ に販売し，温浴施設 $\mathrm{F}$ の職員が薪ボイラーに 薪を投入している。薪製造・投入で専任の雇用はない。薪 の供給を担当している薪供給事業者 $\mathrm{E} て ゙ は$ 薪の製造に従 事した複数名の会員に, 個人の薪の出来高に売上単価から 運営費を除いた金額を乗じた対価を個別に支払っている。 また市外のチップ業者が温浴施設 F にチップを販売し, チップサイロに投入している。ボイラーの保守・管理は温 浴施設 F が担当し必要に応じて業者を手配している。

以上からみられる両者の差異をまとめたのが表-2 と なる。

$\mathrm{A}$ 村では薪の製造, ボイラーへの投入，ボイラーの保 守・管理を熱供給会社 C が一括で担い, ボイラーで発生 する熱のエンドユーザーである温浴施設 D に対して「熱」 を供給している。一方, B 市では薪供給事業者 $\mathrm{E}$ が薪を 製造し，エンドユーザーである温浴施設 $\mathrm{F}$ に「薪」を供 給している。またボイラーへの薪の投入, ボイラーの保 守・管理は温浴施設 F が担っている。したがって，エン ドユーザーである温浴施設がこれまでの燃料供給とは異な り,「熱」の供給を受けているのか, 燃料として灯油の代 わりに「薪」を供給してもらい温浴施設が自ら薪ボイラー を運用しているのかという点で差異がみられた。

温浴施設 $\mathrm{F}$ の職員に運用負荷について話を伺ったとこ ろ，3〜4 時間の間隔で薪を人力で投入するのは確かに負 担ではあるが，新たな人員の雇用が必要となった，あるい は残業時間が増えるという事態には至っていないとのこと であった。一方, チップボイラーの方が薪ボイラーと比 ベ, 前述のチップ品質に起因するトラブルの対応が大変で あり, $6 \mathrm{~m}^{3}$ のチップサイロをすべて人力でさらう必要が あった等，対応に苦慮したとのことであった。

\section{2. 薪ボイラー導入による地域に対する効果}

薪の売り上げによる経済効果ならびに使用量と, 灯油か ら木質バイオマスエネルギーへの代替率を A 村, B 市か ら提供を受けた燃料使用量, 燃費のデー夕を整理し表-3 に示す。なお B 市では前述のトラブルによりチップボイ

表-3. A 村および B 市での経済効果および木質バイオマスエネ ルギーの利用実績の比較

\begin{tabular}{|c|c|c|c|}
\hline 地域 & $A$ 村 & B 市 & $\begin{array}{c}\mathrm{B} \text { 市 (チップボイ } \\
\text { ラー本稼働後) }\end{array}$ \\
\hline 薪供給での売上 & 6711 千円 & 2550 千円 & - \\
\hline 導入前後の燃料コスト & $-26 \%$ & $-27 \%$ & $-56 \%$ \\
\hline 薪の使用量 & $522 \mathrm{t}$ & $300 \mathrm{~m}^{3}$ & - \\
\hline $\begin{array}{l}\text { 木質バイオマスエネルギー } \\
\text { への代替率 }\end{array}$ & $82 \%$ & $55 \%$ & $78 \%$ \\
\hline
\end{tabular}

A 村に関するデー夕は A 村役場から提供資料より 2013 年の燃費および 灯油使用量と 2015 年 4 月から 2016 年 3 月までの燃費および薪・灯油使 用量を基に筆者が作成した。 B 市に関するデー夕は B 市からの提供資料 より 2013 年の燃費および灯油使用量と 2014 年 12 月から 2015 年 11 月ま での燃費抢よび薪・チップ・灯油使用量を基に筆者作成。 B 市のチップ ボイラー本稼働後のデー夕は B 市より提供を受けたバイオマスボイラー の運用データが 2014 年 12 月から 2015 年 11 月のものまでとなっている ため, 2013 年 5 月から 11 月までの灯油使用量とチップボイラーが本稼 働した 2015 年 5 月から同年 11 月までの灯油使用量を比較し作成した。 薪供給での売り上げ・使用量は 2015 年 4 月に供給したものが同年 9 月に 新たに供給されるまで使われておりその間の正確な使用量が不明なため 分析対象としていない。な挍薪の原木は針葉樹を主として複数の樹種が 混じっており正確な変換ができないため, 単位を統一せず両者で管理し ている単位にて記載している。 
ラーの本稼㗢が 2015 年 5 月からとなっているためチップ ボイラー本稼働後のデータを別列にて整理し示す。

熱需要は季節によって変動するため, 導入計画時の 2013 年とチップボイラー本稼働後の 2015 年の同月（5 11 月）の燃費および燃料使用量の実績を比較すると，コスト が $56 \%$ 削減されており，木質バイオマスエネルギーへの 代替率も $78 \%$ となっている。しかしながら，A 村と B 市 の灯油使用量において，A 村が年間を通しての灯油使用量 の変動が比較的なだらか (使用量が最も少ない 8 月が 2013 年度実績で $8,000 \mathrm{~L}$ ，最も多い $1 ， 12$ 月で $14,000 \mathrm{~L} ）$ なの に対して，B市では変動幅が大きい（使用量が最も少ない 8 月が 2013 年度実績で $8,600 \mathrm{~L}$, 最も多い 12 月で 26,100 L）ため，より精度を高めるために通年を通しての分析が 今後必要である。したがってこの結果はあくまで参考的な ものであることを付記しておく。

$\mathrm{A}$ 村， B 市ともに木質バイオマスボイラーの導入によっ て, 導入計画時の 2013 年度灯油使用量・燃費の実績と比 較し, 燃料コスト削減が行えたことが見て取れる。また薪 供給量は数百 $\mathrm{m}^{3}$ となっており, そこで得られる数百万円 単位の売り上げが原木代や人件費として地域への投資と なっている。ただし灯油価格が導入計画時の 2013 年より 大幅に值下げしているため, この結果からは一概にコスト 削減に効果があったとはいえない。また本調査では稼働後 1 年前後の運用実績を基に分析を行っているため, 設備整 備にかかわる初期投資の回収については灯油価格の変動も ふまえ数年間の実績を基に分析を行う必要があり，今回は 分析できなかった。

温浴施設に供給される薪の価格設定については，A 村， B 市ともに両地域を集材範囲としている木質バイオマス発 電施設での取引価格を意識しているという共通点がみられ た。両地域とも木質バイオマス発電施設での取引価格より 若干安価な額で原木を購入し，そこに加工費や運営費等を 積み上げ薪の価格設定を行っている。この価格設定の背景 には，発電所よりも購入価格は低いが，輸送コストと手間 が少なくてすむという点が，林業事業体にとって取引のイ ンセンティブになると期待しているという意図がある。ま た $\mathrm{A}$ 村では原木が $100 \%$ 村内産材ではないにしても，地 域産材を地域で薪に加工し供給しているため, 地域内の工 ネルギー自給の向上に寄与している。

$\mathrm{A}$ 村と $\mathrm{B}$ 市の木質バイオマスの代替率の差異について, 一番大きな要因として B 市ではチップの品質によるトラ ブルでチップボイラーの本稼働が 2015 年 5 月からとなっ たことが挙げられる。その間，温浴施設 F は薪ボイラー と灯油ボイラーのみで熱を賄っており，予定外の灯油の消 費があった。また 2013 年の灯油の使用実績によると温浴 施設 D に比べ温浴施設 $\mathrm{F}$ は冬季と夏季の熱需要の変動が 大きい点や木質バイオマスボイラーの規模，眝湯タンクの 大きさの違い（温浴施設 $\mathrm{D}, 10 \mathrm{t}$; 温浴施設 $\mathrm{F}, 8 \mathrm{t}$ ) も要 因として考えられる。

\section{VI. まとめと今後の展望}

今回の調查によって, 出力規模 $100 \mathrm{~kW}$ 以上の薪ボイ
ラーを導入した地域では，地域産材を地域で加工しエネル ギーとして利用するという地域内エネルギー自給の向上と いう観点が根底にあることがわかった。

ボイラーの運用面について，A 村，B市では運用方法に 差異があり， $\mathrm{A}$ 村は熱供給事業の形式をとっており利用者 負担が少ないというメリットはあるが, 事業体の立ち上げ や運用において専門的な知識を持った人材の確保という ハードルの高さがある。一方, $\mathrm{B}$ 市においては熱源を石油 ボイラーのシステムから木質バイオマスボイラーをメイン としたシステムに転換しているシンプルなものであるた め, 燃料の供給さえ受けることができればどの地域でも適 用できる可能性は高いが，ボイラーの運用が導入施設の負 担となっている。B市の温浴施設 F では 1 日 3 4 回のボ イラーへの薪投入が負荷となっていることは課題だが, 残 業時間が増える等，経営への影響は見受けられなかった。 人力によるところの大きい薪ボイラーではあるが， 100 $\mathrm{kW}$ 以上の規模でも経営に影響を及ぼすことなく運用可能 であることがわかった。一方, チップの品質が合わないこ とからチップボイラーが稼働しないという, チップの品質 に留意が必要という先行研究の指摘をそのまま示す結果も 出ている。このことから薪ボイラーの運用が人力によると ころが大きいという点はもちろんのこと，チップボイラー においてもトラブルが発生したという点を鑑みると，専門 的な知識を有する事業体が熱を供給するという A 村の運 用体制がよりメリットが多いように見受けられた。

地域産材を利用し地域内で薪にすることで, 数百万円規 模の売り上げがあり，地域に対する投資となっている。燃 料費は導入計画時の灯油価格であれば 2 割程度削減できて いる。しかしながら A 村において専任社員の雇用 1 名が 見受けられたが, その人件費や経費は地域おこし協力隊事 業から支出されているため, 実際のエネルギー事業の収益 によって賄われているわけではない。したがって，人件費 を持続的に支出できるかは未知数である。また本調査では 分析対象としていない灯油価格の変動を踏まえイニシャル コストの回収が可能かという点や, 燃料コスト以外の固定 費も含めた経済性, 薪ボイラー用の薪の製造コストや生産 効率の調査も，今後の課題としてあげられる。

今後, 小規模バイオマスの熱利用が普及するための布石 として, 新たなシステムの構築一日本版木質バイオマス小 規模熱供給事業のシステム検討が大きな課題であると考 える。

本研究を行うにあたり, 東北芸術工科大学建築・デザイン学科の 三浦秀一教授並びに公益財団法人自然エネルギー財団の相川高信氏, また金沢大学の大野智彦准教授，蜂屋大八准教授にご助言いただい た。ここに記して篤く御礼申し上げる。本研究での調査において多 大なるご協力をいただいた関係各位の皆様に心より御礼申し上げる。

本研究は, MEXT/JSPS 科研費 JP26360062, JP15H01597 おょび (公財) 平和中島財団, (公財) クリ夕水環境科学振興財団, 総合地 球環境学研究所 : 実践プロジェクトインキュベーション研究, 環境 省環境研究総合推進費（課題番号 1-1303，S15-2（3））, イオン液体 駆動型 里山バイオマス・リファイナリーに関する教育・研究拠点形 成の一環として実施された。 


\section{注記}

（注 1）：2016 年 5 月 17 日に南研市クリエイタープラザで開催された 「南砥市エコビレッジ構想＼cjkstart里山エネルギーで拓く地域の未来」 での三浦秀一氏の講演より。

(注 2)：2016 年 5 月 17 日に南砥市クリエイタープラザで開催された 「南研市エコビレッジ構想＼cjkstart里山エネルギーで拓く地域の未来」 において三浦秀一氏に対する筆者の質疑の回答より。

（注 3）：2016 年 5 月 17 日に南砥市クリエイタープラザで開催された 「南研市エコビレッジ構想里山エネルギーで拓く地域の未来」 での南吥市担当者からのエコビレッジ構想の事業説明より。

\section{引用文献}

相川高信（2014）林業地域が成功する条件とは何か．全国林業改良 普及協会

相川高信・伊藤幸男・菅真由美・紫波グリーンエネルギー株式会 社・中岸良太・小木曾秀美・B スタイル PJ 研究グループ・三木 聡・森 大顕 (2016) 木質バイオマス熱利用でエネルギーの地 産地消。林業改良普及協会

安藤範親（2014）未利用材の供給不足が懸念される木質バイオマス 発電. 農林金融 67(6): 64-378

伊藤幸男（2012）木質バイオマスエネルギーによる地域再生の可能 性と戦略. 農業市場研究 21(3): 3-12

金澤 徹（2014）FIT 制度以降の木質バイオマス発電の展開と林業
の自立的発展. 龍谷大学大学院政策学研究 3: 39-70

季刊地域編集部（2013）福島県の小さな村, に舵を切る。季刊地域 12: $38-43$

近藤加代子（2015）日本の木質バイオマスと地域林業の課題．都市 問題 106(5): 74-81

熊崎 実（2011）木質エネルギービジネスの展望．全国林業改良普 及協会

熊崎 実（2013）木のエネルギーの基本.（木質資源とことん活用読 本. 熊崎 実・沢辺 攻編著, 農山漁村文化協会)。33-51

三浦秀一（2013）木質燃料によるバイオマス地域熱供給システム （木質資源とことん活用読本. 熊崎 実・沢辺 攻編著, 農山漁 村文化協会). 125-137

森 大顕（2016）薪ボイラー導入の手引き。（木質バイオマス熱利用 でエネルギーの地産地消. 相川高信・伊藤幸男・菅真由美・紫 波グリーンエネルギー株式会社・中岸良太・小曽秀美・B タイル PJ 研究グループ・三木 聡・森 大顕著, 国林業改良普 及協会). 200-211

Pa A, Bi XT, Sokhansanj S (2013) Evaluation of wood pellet application for residential heating in British Columbia based on a streamlined life cycle analysis. Biomass Bioenergy 49: 109-122

林野庁（2016）平成 27 年度森林及び林業の動向・平成 27 年度森林 及び林業施策

Trømborg E, Bolkesjø TF, Solberg B (2008) Biomass market and trade in Norway: Status and future prospect. Biomass Bioenergy 32: 660-671 山下英俊・藤井康平 (2015) エネルギー別に見た自治体の再生可能 エネルギーに対する取り組み。都市問題 106(5): 44-55 